\title{
Karakteristik Densitas Tulang Anak dengan Hiperplasia Adrenal Kongenital yang Mendapat Terapi Glukokortikoid
}

\author{
Ariani Dewi Widodo, Jose R. L. Batubara, Evita B. Ifran, Arwin AP Akib, Sudung O. \\ Pardede, Darmawan B. Setyanto \\ Departemen Ilmu Kesehatan Anak Fakultas Kedokteran Universitas Indonesia/Rumah Sakit Cipto \\ Mangunkusumo, Jakarta
}

Latar belakang. Anak dengan hiperplasia adrenal kongenital (HAK) mendapat terapi glukokortikoid seumur hidup. Penggunaan glukokortikoid jangka panjang diketahui dapat menyebabkan penurunan densitas mineral tulang (DMT), namun pada anak HAK terapi tersebut bersifat substitusi. Belum diketahui karakteristik DMT pada anak HAK di Indonesia.

Tujuan. Mengetahui karakteristik densitas tulang anak dengan HAK yang mendapat terapi glukokortikoid.

Metode. Uji potong lintang deskriptif dilakukan di Poliklinik Endokrinologi Departemen Ilmu Kesehatan Anak RSUPN Cipto Mangunkusumo selama November 2008-April 2010. Subjek adalah anak HAK yang mendapat terapi glukokortikoid teratur lebih dari 6 bulan. Pada setiap subjek dilakukan pencatatan data dan pemeriksaan DMT menggunakan dual energy $x$-ray absorptiometry (DEXA) di Klinik Teratai RSUPNCM.

Hasil. Tigapuluh dua subjek, 25 perempuan dan 7 lelaki, 18 dengan HAK tipe virilisasi sederhana dan 14 tipe salt-losing, diikutsertakan dalam penelitian, median usia 6 tahun. Diagnosis 24 subjek ditegakkan pada usia $<1$ tahun, tipe salt-losing terdiagnosis pada usia lebih muda. Semua subjek memiliki status gizi baik hingga obesitas, dan 29/32 subjek memiliki status pubertas sesuai usia. Semua pasien HAK mendapat terapi glukokortikoid teratur sejak saat diagnosis, dengan median dosis $17,7 \mathrm{mg} / \mathrm{m}^{2} / \mathrm{hari}$ atau $3,8 \mathrm{gram}$ dalam 6 bulan terakhir, dan rerata lama pengobatan 7,7 tahun. Terapi mineralokortikoid pada subjek dengan median dosis $50 \mathrm{mcg} /$ hari. Ditemukan DMT normal pada 24/32 subjek, 7 osteopenia, dan 1 osteoporosis. Delapan di antara pasien dengan DMT normal, memiliki $Z$-score $>+1$. Rerata $Z$-score DMT L1-L4 subjek +0,29 (SB 1,46). Terdapat korelasi lemah antara DMT dengan dosis kumulatif glukokortikoid enam bulan terakhir $(\mathrm{r}=-0,36 ; \mathrm{p}=0,04)$, dan tidak ditemukan korelasi dengan dosis glukokortikoid/LPB/hari $(\mathrm{r}=-0,29 ; \mathrm{p}=0,11)$ maupun dengan durasi terapi $(r=-0,07 ; p=0,69)$.

Kesimpulan. Sebagian besar anak HAK yang mendapat terapi substitusi glukokortikoid memiliki DMT normal. Terdapat korelasi lemah antara DMT dengan dosis kumulatif glukokortikoid enam bulan terakhir, sehingga diperlukan penelitian lebih lanjut dengan durasi dosis kumulatif yang berbeda-beda. Sari Pediatri $2011 ; 12(5): 307-14$.

Kata kunci: hiperplasia adrenal kongenital, glukokortikoid, densitas mineral tulang, anak, dual energy $x$-ray absorptiometry

Alamat korespondensi:

Dr. Jose R.L. Batubara, Sp.A(K), PhD. Departemen Ilmu Kesehatan Anak

FKUI/RSCM Jl. Salemba 6 Jakarta. Telp./fax.: 021-3915712

Sari Pediatri, Vol. 12, No. 5, Februari 2011 
$\mathrm{H}$ iperplasia adrenal kongenital (HAK) atau congenital adrenal hyperplasia $(\mathrm{CAH})$ adalah kelainan autosomal resesif yang ditandai dengan adanya defisiensi salah satu dari lima enzim yang diperlukan dalam sintesis kortisol pada korteks adrenal. ${ }^{1-3}$ Gangguan sintesis kortisol mengurangi umpan balik negatif ke hipotalamus dan hipofisis, sehingga produksi corticotropin-releasing hormone $(\mathrm{CRH})$ oleh hipotalamus dan adrenocorticotropic hormone (ACTH) oleh hipofisis meningkat. Proses ini menyebabkan kelenjar adrenal mengalami hiperplasia dan terjadi virilisasi akibat penumpukan androgen., ${ }^{2,4}$

Anak dengan HAK mendapatkan terapi glukokortikoid sejak saat diagnosis. ${ }^{5}$ Terapi HAK terdiri dari glukokortikoid dan mineralokortikoid jangka panjang. ${ }^{2}$ Glukokortikoid dapat menggantikan fungsi kortisol yang defisien dan menurunkan produksi ACTH serta stimulasi korteks adrenal yang berlebihan, sehingga menurunkan sekresi androgen oleh kelenjar adrenal. ${ }^{2}$ Terapi steroid jangka panjang diketahui dapat menyebabkan penurunan bone mineral density (BMD) atau densitas mineral tulang (DMT), namun belum dapat dipastikan apakah terapi glukokortikoid mempengaruhi massa tulang pada pasien HAK. ${ }^{2}$

Tujuan penelitian untuk mengetahui karakteristik DMT pasien anak dengan HAK yang mendapat terapi glukokortikoid, dan mengetahui korelasi antara DMT dengan terapi glukokortikoid pada anak dengan HAK yang telah mendapat terapi glukokortikoid selama minimal enam bulan.

\section{Metode}

Penelitian menggunakan desain potong lintang (crosssectional) deskriptif untuk mengetahui karakteristik demografi, manifestasi klinis, serta gambaran DMT anak HAK. Semua pasien anak dengan HAK lama maupun baru berusia antara 5-18 tahun yang datang ke Poliklinik Endokrinologi Anak Rumah Sakit Umum Pusat Nasional Cipto Mangunkusumo (RSCM) Jakarta antara 1 November 2008 hingga 31 Oktober 2009, mendapat terapi glukokortikoid teratur selama sedikitnya 6 bulan, dapat dilakukan pemeriksaan DMT, dan setuju ikut serta dalam penelitian. Penelitian kemudian diperpanjang hingga April 2010 karena besar sampel yang belum memenuhi besar sampel minimal. Penelitian diakhiri April 2010 karena keterbatasan waktu dan sumber daya, serta kecilnya kemungkinan mendapatkan subjek baru, mengingat data Poliklinik Endokrinologi Anak RSCM hanya mencatat 37 pasien baru yang memenuhi kriteria diagnostik HAK dalam kurun waktu 1990-2006. ${ }^{6}$

Formulir penelitian diisi untuk semua sampel yang memenuhi kriteria penelitian, meliputi data: identitas pasien (nama, umur/tanggal lahir, jenis kelamin), anamnesis (keluhan saat pertama kali datang, riwayat HAK dalam keluarga, identitas gender), pemeriksaan fisis (berat badan dan tinggi badan, indeks massa tubuh, genitalia, status pubertas, tanda virilisasi), dan data sekunder yang diambil dari catatan medis (usia awitan sakit, riwayat krisis adrenal, dosis dan lama terapi glukokortikoid, dosis mineralokortikoid, dosis kumulatif glukokortikoid selama 6 bulan terakhir).

Pasien dijadwalkan untuk pemeriksaan DMT di Klinik Teratai Unit Densitometri PEROSI/ Departemen Ilmu Penyakit Dalam FKUI/RSCM. Pemeriksaan DMT dilakukan menggunakan alat Lunar Prodigy Vision DXA system pada vertebra L1-L4, dengan software pediatrik. Pemeriksaan DEXA dilakukan dengan prosedur standar sesuai petunjuk produsen untuk pemindaian dan analisis. Semua pemeriksaan DMT dilakukan seorang teknisi berpengalaman, dan kalibrasi dilakukan secara berkala menggunakan disk kalibrasi (setiap hari) dan Lunar phantom (setiap bulan). Nilai rujukan yang digunakan adalah berdasarkan usia, jenis kelamin, dan etnis (Asia). Selanjutnya data diolah dan disajikan dalam bentuk tabel dan diagram yang sesuai. Persetujuan etik penelitian diperoleh dari Komisi Etik Penelitian Fakultas Kedokteran Universitas Indonesia.

\section{Hasil}

Selama November 2008-April 2010, terdapat 88 kunjungan anak HAK ke Poliklinik Endokrinologi Anak RSUPN Cipto Mangunkusumo. Dari 88 kunjungan, 46 anak berusia $<5$ tahun, 8 anak usia $\geq 5$ tahun tidak minum obat secara teratur dalam enam bulan terakhir, dan 2 pasien menolak untuk ikut serta dalam penelitian, sehingga didapatkan 32 anak HAK yang memenuhi kriteria dan diikutsertakan sebagai subjek penelitian (Gambar 1).

Sebagian besar subjek adalah perempuan dengan rasio perempuan dan laki-laki 3,6:1 dan median (rentang) usia awitan $6(5-16,5)$ tahun (Tabel 1). 
88 orang anak dengan HAK datang kontrol ke Poliklinik Endokrinologi Anak RSUPN Cipto Mangunkusumo selama November 2008-April 2010

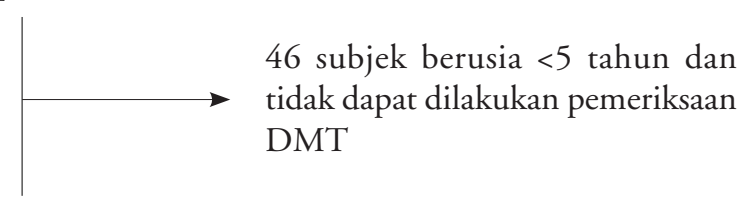

42 orang anak berusia $>5$ tahun dan telah terdiagnosis

HAK $>6$ bulan, serta mendapat terapi glukokortikoid

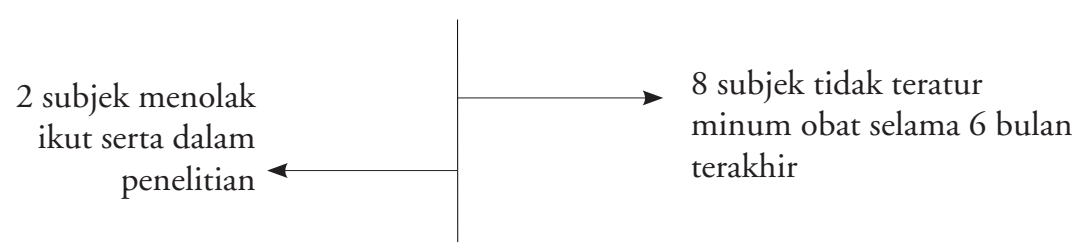

32 anak HAK berusia $>5$ tahun dan mendapat terapi glukokortikoid secara teratur $>6$ bulan

Gambar 1. Alur pengambilan sampel penelitian

Sebagian besar subjek (19/32) berada dalam kelompok usia prapubertas ( $<8$ tahun), dan 11 subjek terdiagnosis dini usia $<1$ bulan.

Tidak ada subjek dengan status gizi kurang, sebagian besar (13/32) memiliki status gizi baik dan 11 subjek obesitas. Sembilan subjek sudah mengalami pubertas dan 23 subjek belum, dan sebagian besar (29 subjek) menunjukkan status pubertas sesuai usia. Di antara subjek laki-laki, 2 orang mengalami pubertas prekoks dan lima orang sisanya memiliki status pubertas sesuai usia. Median (rentang) berat badan subjek adalah $31,5(14-73) \mathrm{kg}$, rerata (SB) tinggi badan $130,8(17,16) \mathrm{cm}$, sedangkan rerata (SB) IMT subjek 19,9 $(4,68) \mathrm{kg} / \mathrm{m}^{2}$ (Tabel 1).

\section{Karakteristik terapi subjek penelitian}

Dilaporkan 18 subjek mendapat terapi glukokortikoid saja, sedangkan 14 di antaranya mendapat terapi glukokortikoid dan mineralokortikoid. Dosis glukokortikoid diberikan menurut luas permukaan badan (LPB) dan keadaan klinis. Rerata (SB) LPB subjek penelitian adalah $1,1(0,31) \mathrm{m}^{2}$. Rentang dosis glukokortikoid $5,2-31,64 \mathrm{mg} / \mathrm{m}^{2}$, dengan rerata 18,6 $(\mathrm{SB} 6,86) \mathrm{mg} / \mathrm{m}^{2} /$ hari. Selama enam bulan terakhir, rerata $(\mathrm{SB})$ dosis glukokortikoid total yang diterima 3815,6 (2025,93) mg (Tabel 2).
Tabel 1. Karakteristik demografi dan klinis subjek penelitian

\begin{tabular}{lc}
$(\mathrm{n}=32)$ & \\
\hline Karakteristik & Jumlah \\
\hline Jenis kelamin & 7 \\
$\quad$ Laki-laki & 25 \\
$\quad$ Perempuan & \\
Usia saat diagnosis (bulan) & 11 \\
$\quad<1$ & 13 \\
12 & 8 \\
$>12$ & \\
Usia kronologis (tahun) & 19 \\
$<8$ & 8 \\
$8-14$ & 5 \\
$>14$ & \\
Ambigus sejak lahir & 22 \\
$\quad$ Ya & 10 \\
Tidak & \\
Status gizi & 0 \\
$\quad$ Kurang & 13 \\
Baik & 8 \\
Lebih & 11 \\
Obesitas & \\
Status pubertas & 9 \\
Sudah & 23 \\
Belum & \\
Kesesuaian status pubertas & 29 \\
Sesuai & 2 \\
Prekoks & 1 \\
Terlambat &
\end{tabular}


Tabel 2. Karakteristik terapi subjek penelitian $(\mathrm{n}=32)$

\begin{tabular}{lccc}
\hline Terapi glukokortikoid & Rerata (SB) & IK 95\% & Median (rentang) \\
\hline Dosis glukokortikoid /LPB/hari (mg/m²/hari) & $18,6(6,86)$ & $16,20-20,95$ & $17,65(5,2-31,64)$ \\
Dosis glukokortikoid kumulatif 6 bulan (mg) & $3815,6(2025,93)$ & $3113,67-4517,57$ & $3600(900-9000)$ \\
Dosis mineralokortikoid (mcg/hari, n=14) & $78,6(42,58)$ & $56,26-100,88$ & $50(50-200)$ \\
Durasi terapi (tahun) & $7,7(3,91)$ & $6,34-9,05$ & $6,1(1,5-16,4)$ \\
\hline
\end{tabular}

Median (rentang) durasi terapi glukokortikoid 6,1 (1,5-16,4) tahun. Pada 14 subjek yang mendapat mineralokortikoid, median (rentang) dosis yang diterima 50 (50-200) mcg/hari.

\section{Karakteristik densitas mineral tulang pada anak dengan HAK}

Pada seluruh subjek dengan HAK yang mendapat tera pi glukokortikoid $\geq 6$ bulan, DMT normal dijumpai pada 24 subjek. Tujuh subjek mengalami osteopenia dan satu subjek mengalami osteoporosis (Gambar 2). Secara kuantitatif, rerata (SB) densitas mineral tulang subjek penelitian $0,78(0,2) \mathrm{g} / \mathrm{cm}^{2}$ dengan rerata $(\mathrm{SB})$ $Z$-score $+0,29(1,46)$. Nilai median (rentang) bone

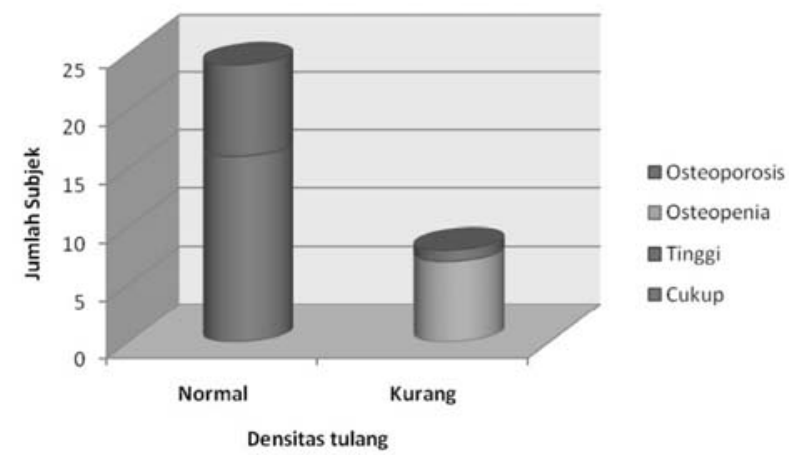

Gambar 2. Distribusi data DMT subjek penelitian mineral content (BMC) 22,55 (9,7-68,4) g. Dari subjek yang memiliki DMT normal, terdapat 8 subjek dengan DMT di atas +1 SB, lebih tinggi dibandingkan DMT menurut usia dan jenis kelamin anak seusianya.

\section{Hubungan antara terapi glukokortikoid dengan DMT}

Perbandingan karakteristik terapi berdasarkan klasifikasi DMT tertera pada Tabel 3. Subjek pada kelompok DMT lebih, normal, maupun kurang memiliki rerata usia yang tidak jauh berbeda.

Analisis data dengan uji korelasi Spearman (Tabel 4) menunjukkan tidak ada hubungan bermakna

Tabel 4. Korelasi antara klasifikasi Z-score dengan dosis dan durasi terapi, usia, dan IMT

\begin{tabular}{lcc}
\hline \multirow{2}{*}{ Terapi glukokortikoid } & \multicolumn{2}{c}{$\begin{array}{c}\text { Klasifikasi z score (normal- } \\
\text { osteopenia-osteoporosis) }\end{array}$} \\
\cline { 2 - 3 } & $\begin{array}{c}\text { Koefisien } \\
\text { korelasi (r) }\end{array}$ & $\mathrm{p}$ \\
\hline Dosis glukokortikoid/LPB & $-0,29$ & 0,11 \\
Dosis glukokortikoid & $-0,36$ & 0,04 \\
kumulatif 6 bulan & & \\
Durasi terapi & $-0,07$ & 0,69 \\
Usia & $-0,10$ & 0,58 \\
IMT & 0,35 & 0,05 \\
\hline
\end{tabular}

Keterangan: Spearman rank test

Tabel 3. Karakteristik terapi berdasarkan klasifikasi DMT* $(n=32)$

\begin{tabular}{|c|c|c|c|c|}
\hline \multirow{2}{*}{ Parameter } & \multicolumn{3}{|c|}{ Rerata (SB) } & \multirow[b]{2}{*}{$\mathrm{p}$} \\
\hline & DMT Lebih & DMT Normal & DMT Kurang & \\
\hline Usia (tahun) & $8,2(2,71)$ & $8,0(3,34)$ & $8,2(5,01)$ & 0,692 \\
\hline Usia saat diagnosis (bulan) & $12,0(15,83)$ & $9,2(18,51)$ & $11,0(21,14)$ & 0,826 \\
\hline $\operatorname{IMT}\left(\mathrm{kg} / \mathrm{m}^{2}\right)$ & $22,5(4,64)$ & $18,8(3,31)$ & $19,8(6,42)$ & 0,236 \\
\hline Dosis glukokortikoid & $21,5(6,78)$ & $16,8(6,26)$ & $19,2(7,84)$ & 0,374 \\
\hline Dosis kumulatif (mg) & $4980,0(2200,57)$ & $3358,1(1487,5)$ & $3566,3(2548,28)$ & 0,248 \\
\hline$Z$-score L1-L4 & $+2,03(1,08)$ & $+0,18(0,83)$ & $-1,24(0,81)$ & 0,000 \\
\hline DMT L1-L4 $\left(\mathrm{g} / \mathrm{cm}^{2}\right)$ & $0,94(0,18)$ & $0,76(0,16)$ & $0,65(0,2)$ & 0,012 \\
\hline BMC L1-L4 (g) & $35,9(16,06)$ & $26,1(11,3)$ & $20,5(14,4)$ & 0,052 \\
\hline
\end{tabular}

${ }^{*} \mathrm{DMT}=$ densitas mineral tulang/LPB/hari $\left(\mathrm{mg} / \mathrm{m}^{2} /\right.$ hari $)$ 
antara klasifikasi Z-score DMT L1-L4 dan dosis terapi glukokortikoid baik untuk dosis per LPB per hari $(\mathrm{r}=0,29 ; \mathrm{p}=0,11)$ maupun durasi terapi glukokortikoid $(\mathrm{r}=0,07 ; \mathrm{p}=0,69)$. Dosis kumulatif glukokortikoid menunjukkan hubungan bermakna dengan klasifikasi $Z$-score DMT, meskipun dengan korelasi lemah ( $\mathrm{r}=0,36$; $\mathrm{p}=0,04)$. Klasifikasi $Z$-score DMT juga menunjukkan korelasi sangat lemah dengan IMT $(r=0,35 ; \mathrm{p}=0,05)$.

\section{Pembahasan}

Telaah literatur mengenai dampak terapi glukokortikoid pada pasien HAK menunjukkan hasil yang sangat bervariasi dan tidak konklusif. Sulit melakukan perbandingan data, karena penelitian yang ada memiliki perbedaan rentang usia yang sangat luas, dan terdapat perbedaan besar dalam hal penilaian karakteristik klinis, parameter laboratorium dan nilai normal yang digunakan, dosis dan jenis glukokortikoid, teknik penilaian DMT, serta hasil penelitian yang saling kontradiktif. Selain itu, sebagian besar anak dengan HAK berada pada usia muda dan tidak dapat dilakukan pemeriksaan DEXA.

Algoritme diagnosis dan terapi pada anak seringkali diterapkan berdasarkan penelitian yang dilakukan pada dewasa. Anak sering diasumsikan memiliki respons yang sama terhadap penyakit atau terapi seperti pada dewasa, padahal anak memiliki beberapa mekanisme fisiologis yang berbeda. Salah satunya, perlu dipertanyakan apakah pemberian glukokortikoid akan memberikan dampak yang sama pada tulang anak HAK yang sedang bertumbuh dibandingkan dengan tulang dewasa.

Perbandingan subjek perempuan dan lelaki 3,6:1, sesuai epidemiologi HAK yang lebih sering ditemukan pada perempuan karena tampilan klinis yang lebih jelas. Penelitian sebelumnya juga menemukan hal serupa meskipun dengan rasio yang lebih kecil, seperti Gussinyé dkk $(2,3: 1),{ }^{7}$ Girgis dan Winter $(1,25: 1),{ }^{5}$ dan Guo dkk (2:1). ${ }^{8}$

Pada umumnya HAK terdiagnosis dalam usia yang relatif dini, terutama pada tipe salt-losing, sehingga lebih banyak anak HAK berobat teratur pada usia bayi dan balita. Di Poliklinik Endokrinologi Anak RSCM, 52\% dari seluruh pasien HAK berusia $<5$ tahun. Penelitian yang mendapatkan usia termuda 5 tahun kemungkinan juga terbentur kendala alat di tempat masing-masing meskipun tidak diutarakan secara eksplisit dalam artikel publikasi.
Sebanyak 24 dari 32 subjek terdiagnosis dini pada usia kurang dari 1 tahun, dan 11 subjek didiagnosis pada usia kurang dari 1 bulan. Rerata IMT subjek 19,9 (SB 4,68) kg/m². Anak dengan HAK memiliki kecenderungan IMT berlebih karena rasio masa lemak dengan lean mass lebih tinggi dibandingkan anak normal, yang sudah dibuktikan oleh Cameron dkk. ${ }^{9}$ Konsumsi glukokortikoid menyebabkan retensi air dan meningkatkan nafsu makan. Charmandari $\mathrm{dkk}^{10}$ menemukan bahwa kadar leptin pada anak HAK lebih tinggi dibandingkan anak normal, disertai peningkatan kadar insulin dan resistensi terhadap insulin. Semua faktor tersebut dapat berperan dalam menyebabkan obesitas pada 11 subjek dalam penelitian ini. Anak HAK dengan obesitas memiliki risiko mengalami berbagai penyakit pada masa dewasa, salah satunya penebalan tunika intima-media pembuluh darah yang telah dibuktikan oleh Sartorato dkk, ${ }^{11}$ merupakan faktor risiko stroke dan infark miokard di masa mendatang.

Hanya 1 dari 25 subjek perempuan mengalami pubertas terlambat, sesuai karakteristik HAK yang mengalami virilisasi dan seharusnya berisiko pubertas prekoks perifer (GnRH-independent precocious puberty). Manifestasi klinis pada anak perempuan salah satunya dapat berupa rerata usia menarke yang lebih tua dibandingkan anak perempuan normal. ${ }^{12}$ Pasien yang mengalami keterlambatan pubertas adalah seorang anak perempuan berusia 13 tahun 9 bulan dengan riwayat ibu menstruasi terlambat, sehingga masih mungkin suatu keterlambatan pubertas konstitusional. Sedikitnya subjek yang mengalami kelainan pubertas merupakan salah satu faktor yang mendukung bahwa terapi cukup adekuat.

Tinggi akhir anak HAK seringkali -1 sampai -2 SD di bawah rerata populasi umum, karena percepatan laju pertumbuhan dan penutupan dini epifisis. ${ }^{12,13}$ Paparan berlebih terhadap hormon androgen menyebabkan maturasi tulang secara cepat, dan paparan berlebih terhadap glukokortikoid yang menyebabkan gangguan pertumbuhan. Pubertas prekoks juga dapat berperan pada terjadinya hambatan pertumbuhan. Kegagalan pertumbuhan pada usia muda lebih merupakan indikator dosis glukokortikoid yang berlebih. Nguyen dkk. ${ }^{13}$ dalam telaahnya menyatakan bahwa pasien laki-laki dengan HAK tipe virilisasi sederhana memiliki prognosis tinggi badan paling buruk, karena diagnosis dan terapi yang terlambat. Pada penelitian kami, kedua subjek dengan perawakan pendek adalah 
lelaki berusia 16,5 tahun dan perempuan berusia 15,3 tahun, keduanya pada ekstrim usia terbesar. Usia tulang mereka secara berturutan 4 dan 3 tahun lebih tua dari usia kronologis, sehingga perawakan pendek kemungkinan disebabkan HAK itu sendiri atau terapi glukokortikoid.

Semua pasien HAK pada penelitian kami mendapatkan hidrokortison dan 14/32 subjek mendapat mineralokortikoid. Dosis glukokortikoid diberikan sesuai LPB dan keadaan klinis pasien dengan median (rentang) $17,7(5,2-31,64) \mathrm{mg} / \mathrm{m}^{2} /$ hari. Dosis tersebut sesuai panduan pengobatan HAK, yakni $10-20 \mathrm{mg} / \mathrm{m}^{2} /$ hari. Rerata lama terapi glukokortikoid yang diterima subjek 7,7 tahun, tidak berbeda jauh dengan rerata usia subjek karena semua subjek mendapat terapi glukokortikoid sejak pertama kali didiagnosis, hanya usia diagnosis tiap subjek berbeda-beda. Rerata (SB) dosis glukokortikoid pada penelitian Sciannamblo $\mathrm{dkk}^{2}$ kurang lebih sama, 17,1 $(1,1) \mathrm{mg} / \mathrm{m}^{2} /$ hari.

Pemberian terapi glukokortikoid pada pasien HAK di RSCM tidak selalu dipantau dengan pemeriksaan 17-hidroksiprogesteron (17-OH) karena keterbatasan biaya. Sebagian besar pasien tidak mampu secara ekonomi, dan pemeriksaan tersebut tidak ditanggung jaminan kesehatan yang tersedia. Penyesuaian dosis glukokortikoid seringkali didasarkan pada gejala klinis virilisasi seperti pertambahan tinggi badan secara cepat, warna kulit semakin gelap, tumbuh atau bertambahnya rambut pubis dan aksila, dan tanda pubertas sebelum waktunya.

Waktu dan dosis glukokortikoid yang diberikan juga perlu disesuaikan dengan metabolisme kortisol pada anak HAK, yang tidak diteliti lebih lanjut karena bukan merupakan fokus penelitian ini. Menurut Charmandari dkk, ${ }^{14}$ glukokortikoid sebaiknya diberikan saat aksis hipotalamus-hipofisis-adrenal sedang aktif, yakni pukul 04.00-16.00, dengan dosis terbesar pada pagi hari. Dosis glukokortikoid juga harus disesuaikan saat pasien melakukan aktivitas fisis ${ }^{15}$ dan saat pubertas, ${ }^{16,17}$ karena kecukupan dosis glukokortikoid pada masa pubertas sangat menentukan DMT pada masa dewasa. ${ }^{18}$

Sebagian besar subjek memiliki DMT normal. Beberapa faktor diduga berperan dalam menyebabkan rendahnya DMT pada 8 subjek penelitian. Pertama adalah glukokortikoid. Rerata dosis glukokortikoid pada penelitian ini adalah $18,6(\mathrm{SB} 6,86) \mathrm{mg} / \mathrm{m}^{2} /$ hari serupa dengan beberapa penelitian, di antaranya penelitian oleh Gussinyé $\mathrm{dkk}^{7}$ yang mendapatkan rerata dosis glukokortikoid 21,2 (SB 2,2) $\mathrm{mg} / \mathrm{m}^{2} /$ hari pada kelompok prepubertas dan 22,3 (SB 2,6) $\mathrm{mg} / \mathrm{m}^{2} /$ hari pada kelompok remaja dan dewasa muda, keduanya sedikit lebih tinggi dibandingkan penelitian ini. Pada penelitian Gussinyé $\mathrm{dkk}^{7}$ didapatkan $Z$-score DMT $+0,11$ (SB 1,01). Perbedaan hasil tersebut kemungkinan disebabkan perbedaan dosis glukokortikoid, perbedaan vertebra lumbal yang diperiksa, dan karena penelitian tersebut hanya menggunakan subjek HAK tipe salt-losing, yang diketahui memiliki DMT lebih rendah.

Tidak tampak pola/tren tertentu dosis glukokortikoid harian antara pasien dengan DMT lebih, normal, maupun kurang. Demikian pula tidak tampak pola usia kronologis maupun usia saat diagnosis dengan DMT. Analisis tambahan tidak menemukan hubungan yang bermakna antara klasifikasi $Z$-score DMT L1-L4 dan dosis terapi glukokortikoid per LPB per hari dan durasi terapi glukokortikoid.

Terdapat korelasi lemah antara klasifikasi DMT dengan dosis glukokortikoid kumulatif selama enam bulan terakhir pada penelitian ini. Hal ini didukung oleh penelitian Chakhtoura $\mathrm{dkk}^{19}$ yang menemukan hubungan bermakna antara DMT dengan dosis kumulatif glukokortikoid $(\mathrm{p}<0,001)$ dan dosis ratarata glukokortikoid $(\mathrm{p}=0,02)$ yang diterima subjek sejak saat diagnosis. Perbedaan tingkat kemaknaan pada penelitian tersebut dengan penelitian kami kemungkinan disebabkan usia subjek pada penelitian Chakhtoura lebih tinggi. Belum ada kesepakatan parameter terbaik yang dapat menggambarkan korelasi terapi glukokortikoid dengan pengukuran massa tulang dan metabolisme tulang. Beberapa penelitian memilih dosis kumulatif glukokortikoid selama 6 bulan, 2 tahun, 5 tahun, bahkan 7 tahun terakhir sebagai parameter, berdasarkan pengalaman klinis., ${ }^{2,920,21}$

Masih mungkin terdapat mekanisme lain yang menyebabkan rendahnya DMT. Salah satunya adalah perawakan pendek akibat penutupan dini cakram epifisis sehingga membatasi lamanya pembentukan tulang dan menurunkan bone mineral content (BMC). Masih perlu diteliti apakah durasi terapi glukokortikoid yang lebih panjang memiliki korelasi yang lebih kuat dengan DMT. Faktor lain yang juga dapat berpengaruh pada rendahnya DMT subjek adalah asupan kalsium dan vitamin $\mathrm{D}$, serta aktivitas fisik sebagai faktor pendukung. Masa tulang adalah satusatunya parameter kesehatan tulang yang diperiksa, padahal kekuatan tulang tidak hanya ditentukan 
oleh masa tulang, namun juga oleh geometri tulang, kualitas tulang, dan karakteristik tulang yang tidak dapat dideteksi menggunakan DEXA.

Secara khusus kelebihan yang dimiliki penelitian ini adalah belum adanya penelitian serupa pada populasi anak Indonesia, dan penelitian serupa di negara lain masih sangat terbatas dengan hasil yang tidak konklusif. Pada penelitian kami digunakan jenis terapi glukokortikoid yang sama, dan terdapat perbedaan populasi subjek dibandingkan penelitian lainnya, karena terapi glukokortikoid bersifat substitusi.

\section{Keterbatasan penelitian}

Penelitian yang menggunakan desain potong lintang, tidak memungkinkan pengukuran bone loss atau penurunan kecepatan penumpukan mineral pada setiap pasien. Penelitian pendahuluan perlu dilanjutkan. Beberapa penelitian sebelumnya menggunakan jumlah subjek yang kurang lebih serupa, meskipun tidak diketahui nilai $\mathrm{p}$ yang digunakan sebagai dasar perhitungan misalnya Gussinyé $\mathrm{dkk}^{7}$ (33 subjek), Stikkelbroeck $\mathrm{dkk}^{21}$ (30 subjek), Mora $\mathrm{dkk}^{22}$ (30 subjek), Girgis dan Winter ${ }^{5}$ (28 subjek), dan King $\mathrm{dkk}^{1}$ (26 HAK, 9 kontrol). Alat DEXA hanya dapat memeriksa DMT anak berusia $\geq 5$ tahun. Subjek termuda pada penelitian Freire $\mathrm{dkk}^{23}$ serta Girgis dan Winter ${ }^{5}$ juga berusia 5 tahun, yang kemungkinan karena alasan yang sama. Program pemeriksaan DMT pada bayi belum tersedia di Indonesia dan harganya sangat mahal, sehingga tidak memungkinkan dilakukan.

\section{Kesimpulan}

Sebagian besar anak HAK yang mendapat terapi glukokortikoid teratur adalah perempuan berusia kurang dari 8 tahun yang terdiagnosis pada usia sebelum 1 tahun. Sebagian besar subjek memiliki DMT normal dengan rerata $Z$-score $+0,29$, dan 8 subjek dengan DMT kurang. Terdapat korelasi lemah antara DMT anak HAK dengan dosis kumulatif glukokortikoid selama enam bulan terakhir. Penelitian dengan jumlah subjek lebih besar dan durasi terapi lebih panjang akan memberi informasi lebih banyak mengenai korelasi terapi glukokortikoid dengan penurunan DMT. Perlu ditelaah lebih dalam faktor penyebab DMT rendah pada anak HAK yang mendapat terapi glukokortikoid, termasuk dampak terhadap metabolisme kalsium dan vitamin D. Penelitian mengenai terapi glukokortikoid pada anak HAK harus didukung pemeriksaan kadar testosteron (17-OH) dalam darah untuk memastikan kecukupan dosis glukokortikoid.

\section{Daftar pustaka}

1. King JA, Wisniewski AB, Bankowski BJ, Carson KA, Zacur HA, Migeon CJ. Long-term corticosteroid replacement and bone mineral density in adult women with classical congenital adrenal hyperplasia. J Clin Endocrinol Metab 2006;91:865-9.

2. Sciannamblo M, Russo G, Cuccato D, Chiumello G, Mora S. Reduced bone mineral density and increased bone metabolism rate in young adult patients with 21-hydroxylase deficiency. J Clin Endocrinol Metab 2006;91:4453-8.

3. Speiser PW, White PC. Congenital adrenal hyperplasia. N Engl J Med. 2003;349:776-88.

4. White PC, Speiser PW. Congenital adrenal hyperplasia due to 21-hydroxylase deficiency. Endocr Rev 2000;21:245-91.

5. Girgis R, Winter JS. The effects of glucocorticoid replacement therapy on growth, bone mineral density, and bone turnover markers in children with congenital adrenal hyperplasia. J Clin Endocrinol Metab 1997;82:3926-9.

6. Oswari AW. Deteksi delesi/large gene conversion dan mutasi titik kodon 172 gen CYP21 pada hiperplasia adrenal kongenital. 2007. Jakarta, Universitas Indonesia.

7. Gussinyé M, Carrascosa A, Potau N, Enrubia M, Vicens-Calvet E, Ibáñez L dkk. Bone mineral density in prepubertal and in adolescent and young adult patients with the salt-losing form of congenital adrenal hyperplasia. Pediatrics 1997;100:671-4.

8. Guo C-Y, Weetman AP, Eastell R. Bone turnover and bone mineral density in patients with congenital adrenal hyperplasia. Clin Endocrinol 1996;45:535-41.

9. Cameron FJ, Kaymakci B, Byrt EA, Ebeling PR, Warne GL, Wark JD. Bone mineral density and body composition in congenital adrenal hyperplasia. J Clin Endocrinol Metab 1995;80:2238-43.

10. Charmandari E, Weise M, Bornstein SR, Eisenhofer G, Keil MF, Chrousos GP dkk. Children with classic congenital adrenal hyperplasia have elevated serum leptin concentrations and insulin resistanc wwe: potential clinical implications. J Clin Endocrinol Metab 
2002;87:2114-20.

11. Sartorato P, Zulian E, Benedini S, Mariniello B, Schiavi F, Bilora F dkk. Cardiovascular Risk Factors and Ultrasound Evaluation of Intima-Media Thickness at Common Carotids, Carotid Bulbs, and Femoral and Abdominal Aorta Arteries in Patients with Classic Congenital Adrenal Hyperplasia due to 21-Hydroxylase Deficiency. J Clin Endocrinol Metab 2007;92:1015-8.

12. Carel JC, Leger J. Precocious puberty. N Engl J Med 2008;358:2366-77.

13. Nguyen AT, Brown JJ, Wayne GL. Growth in congenital adrenal hyperplasia. Indian J Pediatr 2006;73:89-93.

14. Charmandari E, Matthews DR, Johnston A, Brook CG, Hindmarsch PC. Serum cortisol and 17hydroxyprogesterone interrelation in classic 21 hydroxylase deficiency: is current replacement therapy satisfactory? J Clin Endocrinol Metab 2001;86:467985.

15. Green-Golan L, Yates C, Drinkard B, VanRyzin C, Eisenhofer G, Weise M dkk. Patients with classic congenital adrenal hyperplasia have decreased epinephrine reserve and defective glycemic control during prolonged moderate-intensity exercise. J Clin Endocrinol Metab 2007;92:3019-24.

16. Bonfig W, Pozza SB, Schmidt H, Pagel P, Knorr D, Schwarz HP. Hydrocortisone dosing during puberty in patients with classical congenital adrenal hyperplasia: an evidence-based recommendation. J Clin Endocrinol Metab 2009;94:3882-8.

17. Charmandari E, Brook CG, Hindmarsch PC. Classic congenital adrenal hyperplasia and puberty. Eur J Endocrinol 2004;151:U77-U82.

18. Falhammar H, Filipsson H, Holmdahl G, Janson PO, Nordenskjöld A, Hagenfeldt K dkk. Fractures and bone mineral density in adult women with 21-hydroxylase deficiency. J Clin Endocrinol Metab 2007;92:4643-9.

19. Chakhtoura Z, Bachelot A, Samara-Boustani D, Ruiz JC, Donadille B, Dulon J dkk. Impact of total cumulative glucocorticoid dose on bone mineral density in patients with 21-hydroxylase deficiency. Eur J Endocrinol 2008;158:879-87.

20. Hagenfeldt K, Ritzén EM, Ringertz H, Helleday J, Carlström K. Bone mass and body composition of adult women with congenital virilizing 21-hydroxylase deficiency after glucocorticoid treatment since infancy. Eur J Endocrinol 2000;143:667-71.

21. Stikkelbroeck NM, Oyen WJ, van der Wilt GJ, Hermus AR, Otten BJ. Normal bone mineral density and lean body mass, but increased fat mass, in young adult patients with congenital adrenal hyperplasia. J Clin Endocrinol Metab 2003;88:1036-42.

22. Mora S, Saggion F, Russo G, Weber G, Bellini A, Prinster $\mathrm{C} \mathrm{dkk}$. Bone density in young patients with congenital adrenal hyperplasia. Bone 1996;18:337-40.

23. Freire PO, Lemos-Marini SV, Maciel-Guerra AT, Morcillo AM, Baptista MT, de Mello MP. Classical congenital adrenal hyperplasia due to 21-hydroxylase deficiency: a cross sectional study of factors involved in bone mineral density. J Bone Miner Metab 2003;21:396401. 